\title{
The Relationship between Strategic Capabilities and Academic Performance: An Empirical Evidence from Sudan
}

\author{
Nahla El Sheikh Hagoug ${ }^{1} \&$ Yousif Abdelbagi Abdalla ${ }^{2}$ \\ ${ }^{1}$ Department of Business Administration, College of Science and Humanities at Alghat, Majmaah University, \\ Majmaah, Saudi Arabia and Department of Business Administration, School of Management Studies, Ahfad \\ University for Women, Sudan \\ 2 Department of Accounting, College of Business Administration, University of Sharjah, Sharjah, United Arab \\ Emirate, and Department of Accounting and Financial Management, School of Management Studies, University of \\ Khartoum, Khartoum, Sudan \\ Correspondence: Nahla Hagoug, Department of Business Administration, College of science and Humanities at \\ Alghat, Majmaah University, Majmaah, Saudi Arabia.
}

Received: December 5, 2020

Accepted: December 18, $2020 \quad$ Online Published: December 23, 2020

doi:10.5430/ijhe.v10n3p46

URL: https://doi.org/10.5430/ijhe.v10n3p46

\begin{abstract}
The objective of this study is to examine the role of strategic capabilities in achieving academic performance in Sudanese private universities. Based on a literature search, an accurate questionnaire was used to collect the needed data.198 questionnaires were collected from Sudanese private universities using the two-stage cluster sampling. For data analysis, multiple regression model was conducted. The findings indicated that the constructs of strategic capabilities including human resources and physical resources are significantly and positively associated with performance. The research concluded that strategic capabilities are the factors of achieving academic performance in private universities in Sudanese context. Moreover, there are a few studies in such field, and there are only few empirical studies that have examined resources' characteristics. This research will expand the body of knowledge of both scholars and practitioners in the area of strategic responses among private universities establishments, as well as identify areas that could be further studied.
\end{abstract}

Keywords: strategic capabilities, human resources, physical resources, academic performance, Sudan

\section{Introduction}

Over the last twenty-six years (1990-2016), the educational sector in Sudan had experienced a tremendous progress (Gasim, 2010; Alboushra et al., 2015). The country's high demand for higher education has pushed this progress. The higher education reform programs adopted in the 1990s concentrated on expanding the country's tertiary education to satisfy the socio-economic development plans' needs as well as to keep up with the growing population.

Sudan is sending thousands of students to further their studies to nations like Iraq, Egypt, Russia, India, and Eastern European countries. Thus, it is asserted that the tertiary education in Sudan needs to be simulated in view that the cost involved when the students are sent to study internationally is significant. However, the pressure of the environment is constantly mounting and organizations are concerned about adapting their operations to fulfil the market's demand and requirement (Ndanu, 2014).

An environmental factor that affects businesses is competition. An industry's attractiveness is threatened when competition increases, and this will reduce businesses' profit. The competition will demand businesses to act proactively and to develop strategies that would appropriately react to real and expected adjustment in their competitiveness (Drucker, 2009). The term 'competitive advantage' emerges due to the importance of competition. It could be as "a concept which describes the degree of relative advantage possessed by an enterprise within its sector or markets as compared with other organizations which it directly or indirectly competes; or with which its use of people, finance, and resources must be compared" (Johnson et al., 2014). For the abilities and resources to be discovered, the management has to search within the organization itself for that priceless, unique and expensive-to -copy resources (Barney, 1991). 
However, organizations are concentrating on getting and sustaining their competitive advantage so that they are able to react, and efficiently compete with their rivals (Johnson et al., 2014). When an organization recognizes its core competencies, it could focus on domains that provide superiority over others, and competitive advantage (Johnson and Scholes 2007). The creation of sustainable performance and competitive advantage is dependent upon the unique resources and abilities that an organization puts forth in the competitive market (Johnson et al., 2014).

Furthermore, a very well-known method in understanding the dynamics of competition is resource-based view (RBV) of firm. The approach stipulates that only priceless, unique, difficult to copy and non-substitutable resources are providing sustainable competitive advantage (SCA) (Barney et al., 2001). Moreover, the strategic capability has a conceptual connection with RBV where both views affirm that rivals cannot imitate the development of idiosyncratic efficiencies (Day, 1994).

However, with the RBV, it is indicated that "while resources are the source of a firm's capabilities, capabilities are the main source of CA and performance" (Nguyen, 2010). On the other hand, Smith (1996) explained that a strategic resource is defined as any resource that has the capability of supplying a firm with competitive advantage. An organization's resources, including its capability and assets constitute the fundamental for SCA (Pandza and Thorpe, 2009). Therefore, this approach suggests that organizations to develop their one-of-the-kind resources and abilities where these will be the organizations' main factors for CA.

Most studies are concern about strategic capabilities in universities and their relationship with performance in developed countries. However, limited studies had been conducted in relation to private universities in developing countries generally, and specifically in Sudanese context (Abdalkrim, 2013). Several scholars (Mahdi and Imsafri, 2014; Jeketule, 2014; Kaluyu et al., 2014) have recommended for more empirical studies on resources and performance.

The literature review shows that several contributions have been made in relation to performance in business organizations, but only few relate to the higher education sector (Aydın, 2013). Therefore, the researchers regard that this study will fill this gap in the study field of strategic capabilities in private universities in Sudan and their role in academic performance.

Therefore, this study intends to analyze the correlation between the two elements of strategic capabilities (i.e. human resources and physical resources) and university performance (i.e. academic performance) in Sudanese private universities. The study's results will indicate the importance of strategic capabilities as the main factor for academic performance. Thus, the results will also be advantageous to researchers of both public and private education institutions in Sudan. This study's outcome will also benefit those with indirect and indirect interests in private education institutions.

\section{Literature Review and Hypotheses Development}

In this section, the researcher looks at previous studies related to the topic under research including both theoretical and empirical studies. The study also seeks to identify the knowledge gaps and develop a conceptual model that depicts the correlation between independent variable and dependent variable. The resource-based view will guide this study. Based on existing literature, we proposed that human resources and physical resources are factors of strategic capabilities.

\subsection{Resource-Based View Theory}

The RBV could be regarded as a widely accepted theory where it concentrates on the correlation between a company's internal characteristics and competitive advantage. The theory stipulates that firms belonging to similar industry have different sets of resources (Talaja 2012; Carmeli, 2004). The resource-based view comes out as a very popular theoretical approach for explaining performance (Newbert, 2008). From the resource-based view perspective, resources are inputs to the production of a firm; and they are categorized into three classes such tangible resources, human resources and organizational resources (Crook et al., 2008)

Previous researchers (Bess, 2001; Armstrong and Shimizu 2007; Anggraini et al., 2018) outline that the firm Resource Based Theory (RBT) confirms the role of the abilities and resources in forming competitive advantage foundation. This shows that RBV focuses on resources that provide competitive advantage in the long term, and considers both types of resources, i.e. tangible and intangible. According to Barney $(1991,2001)$, a prime point of the resource-based theory (RBT) is that, for an organization to fulfill a state of sustained competitive advantage, it should acquire valuable, rare, inimitable and non-substitutable (VRIN) resources and capabilities. Capability refers to the proportion of a group of resources to carry out an extending duty of an activity (Ndanu, 2014). A firm can be referred to as a collection of capabilities that could be developed where they are dynamically managed to achieve 
extraordinary return. Each firm has unique strategic capabilities that provide the foundation for the firm's strategic plans and main factors for its profitability.

\subsection{Strategic Capabilities}

Strategic capabilities (SCs) are capabilities of building up with skills and knowledge of companies in which will synchronize their operation and evaluate their assets to create economic value and accomplish SCA (Day, 1994). As mentioned by Barney (1991), strategic assets should meet the following standards: for valuable resources to be strategic, they should have the power to enhance the effectiveness and efficiency of the firm; rare, non-substitutable and inimitable resources. Previous studies (see for instance, Ismail et al., 2012; Kiru, 2015; Kabue and Kilika, 2016) have shown that resources could be regarded as the basis for accomplishing and maintaining competitive advantage. This will eventually lead to superior organizational performance. A firm's resources are considered as the major element of performance; and the resources are also contributing to sustainable competitive advantage. Kiiru (2015) and Kabu and Kilika (2016) mentioned that a firm will improve, develop and provide products and services to its clients by utilizing its capabilities and resources; in which include human, physical and organizational resources. As such, these resources, physical resources and human resources are used in this study as factors for SCs. Accordingly, we hypothesize that strategic capabilities have a relationship with academic performance. Hence, we hypothesize:

H1 There is a statistically significant correlation between strategic capabilities and academic performance.

\subsection{Dimensions of Strategic Capability}

Scholars operationalized SCs as a predictor that is measured by two indicators; which are human resources and physical resources. This study follows the construct of SCs developed by Ismail et al. (2012); with a reference to (Morgan et al., 2004; Ainuddin et al., 2007). This current research focuses on resources and competence. As a result, this study proffers two components, i.e. human resources and physical resources for SCs as constructs.

\subsubsection{Human Resources}

Wright et al. (1994) mentioned that before explaining and discussing the possibility of human resource for shaping sustainable competitive advantage (SCA), it is imperative to clarify their visualization of human resources. Moreover, human resource is defined as "a human capital pool under the control of firms in a relationship of direct employment". Furthermore, human resource practices are organizational activities directed at human capital management where this approach guarantees that the capital is employed towards the achievement of organizational objective. This will lead to acknowledging two features of human resources.

Firstly, the study by Flamholtz et al. (1981) concentrates on the knowledge, skills and capability ingrained in an organization's workers. Secondly, the study expanded the models where it acknowledged that a firm does not gain anything from workers' attributes unless the workers' behavior is used, which is generally defined. Moreover, a successful realization of a firm's objectives depends on certain employees and the efficient systems of internal organization (Thompson et al., 2007).

Previous research had proven that the correlation between human resources and competitive advantage is significant (Barney, 1991; Thompson and Martin, 2010; Ngugi, 2016; Kabue and Kilika, 2016). Barney (1991) realized that human resources could be the factors of sustained competitive advantage. This is because they satisfy the requirement of being scarce, valuable, unique and cannot be substituted. Kabue and Kilika (2016) confirmed that a human asset is essential for sustained performance. In accordance to the studies mentioned above, we propose that human resources will influence academic performance, so we hypothesize:

H1a There is a statistically significant correlation between Human resources and academic performance.

\subsubsection{Physical Resources}

According to Resource-based view (RBV), physical resources, intangible resources and organizational capabilities are resources that an organization owns and controls (Othman et al., 2015). For the creation of sustainable competitive advantage (SCA), tangible resources (such as physical and financial) as well as intangible resources (such as worker experience, knowledge and firm reputation) were used (Galbreath, 2004). In addition, Grant (2002) pointed out that tangible resource is easily recognized and assessed in view that financial and physical resources are mentioned the organization's financial statement.

In previous studies, they had found a strong link between physical resources and performance (Inmyxai and Takahashi, 2010; Othman, et al., 2015). Machinery, plant, equipment, capacity and production technology are physical resources that emphatically contribute to corporate competitive advantage; and in due course, lead to 
superior performance (Morgan et al., 2004; Ainuddin et al., 2007). In accordance to above argument and past studies' outcomes, we propose that physical resources will influence academic performance. Hence, we hypothesize:

H1b There is a statistically significant correlation between physical resources and performance.

\subsubsection{University Performance}

Performance is considered as crucial for all activities in any firm (Abdel Karim, 2013; Shutibhinyo and Wongkaew, 2018). Wang (2010) argued that, the discussion of performance measurement should be based on understanding what organizational performance is. Furthermore, there is no agreement upon the definition of organizational performance. This is because firms operate in different industries and face various challenges. Meanwhile, organizational performance can be defined as "an extent to which organizational goals are achieved". Organizational performance is defined as a firm achieving its aim in an effective and efficient way (Mackie, 2008). Barney (1991) argued that performance is a continual process to contentious between firm analyzers. However, in evaluating performance, firms should consider the main measure of performance that evolves within their business frameworks. Moreover, the key performance measures have a vital function in the determination of a firm's performance level; and they could be financial and non-financial indicators (Stephen and Nzuve, 2012).

Dyer and Reeve (1995) considered that the main measurements of performance are human resource outcomes, organizational outcomes, financial outcomes and capital market outcomes. Kaplan and Norton (2005) outlined that financial indicators are considered as an early measurement of organizational performance for profit setting. De Boer et al. (2007) indicated that target diversity and opacity distinguished the universities, which are considered as an ordinary phenomenon by certain universities. On the other hand, the objectives of the university are often complex and wide, for example, contribution to regional development, social impact, etc. such that much of the information is concealed and need digesting.

Meanwhile, Wang (2010) argued that there is a criticism due to reliance on financial and accounting models; and this is because of deceptive sign for improvements and in adapting to today's surrounding. Therefore, the universities' performance can be measured through the range in which every task is directed towards the university aims. The author outlines that universities have a major function, which is the academic function. Besides, efficient and effective performance should be founded on the measurement of performance in the university's functions. However, universities are continuously in the state of spreading knowledge and knowledge generation.

Therefore, the measurement of performance in universities has been concentrated on academic performance, which is measured through research performance, training performance, publication performance and education performance.

Accordingly, all of these are summarized in conceptual framework (Figure 1) where it depicts the correlation between the dependent and independent variables. This model is based on the Resource Based View in explaining the dimensions of Academic Performance (ACP).

Therefore, this study adopted (ACP) in universities as the dependent variable (training performance, research performance, publication performance and education performance). Meanwhile, strategic capabilities (human resources, physical resources) are the independent variables. Based on the resource-based view and past studies' outcomes, the hypothesized correlation is determined. There is an association between strategic capabilities and academic performance.

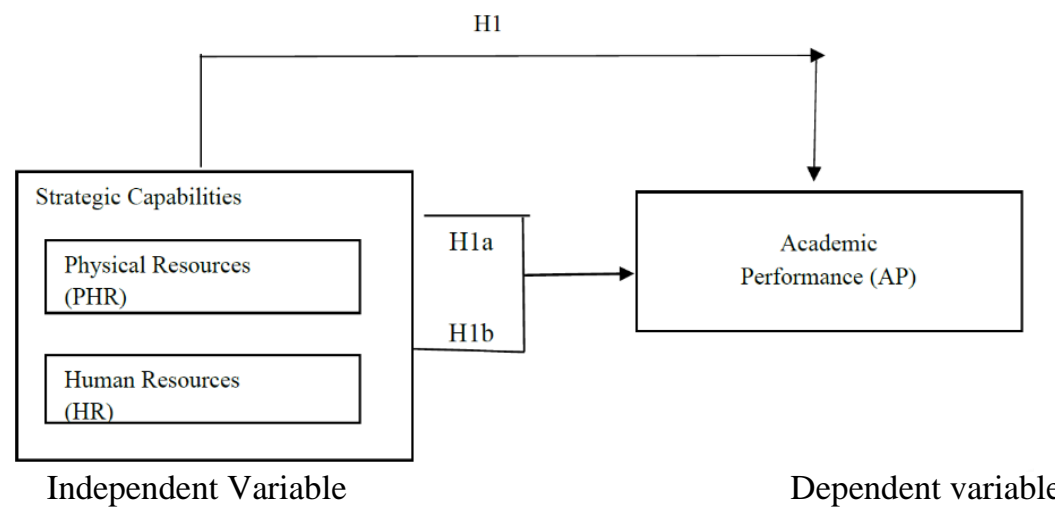

Figure. 1. Conceptual Framework 


\section{Research Methodology}

\subsection{Measurement of the Constructs}

This paper employed the 5-point Likert scale for all measures. The scales ranged between "strongly disagree" and "strongly agree". The scales were adapted from past research in the field of SCs. In particular, SCs were measured by twelve-item scale adapted from Ismail et al. (2012). The independent variable SCs was operationalized through two dimensions, namely human resources and physical resources. The dependent variable, academic performance (ACP) was measured using thirteen items adapted from (Wang, 2010). The four main dimensions of academic performance include, education performance, research performance, publication performance and training performance. The four dimensions were piled together to measure this construct. To build-up the scale of one-dimensionality, principle component factor analysis was utilized to confirm that the items analyzed congregate in a single factor.

\subsection{Sampling Procedure and Data Collection}

This study's population was all the senior managers who work in private universities in the Khartoum state. Sampling was done in accordance to the list of all private universities in the Khartoum state, chosen from the listing furnished by the Department of Admission, Ministry of Higher Education. This sector is made up of 13 private universities. As the probability sampling method is widely accepted and its results can be highly generalized, this study had utilized this approach.

The two-stage cluster sampling method was utilized to choose this study's sample elements (Zikmund, 2003). A simple multistage sampling method of two-stage cluster sampling was done through the selection of cluster samples in the initial phase. Thereafter, the next phase involves the selection of sample elements from all clusters. Accordingly, and based on the list of private universities located in Khartoum state, the selected sample elements were nine universities out of thirteen. A total of 198 questionnaires were given out to senior managers in the nine private universities. 194 valid questionnaires were acquired. The response rate was $97.9 \%$. This rate is considered high due to the fact that the questionnaires were individually given to the respondents (Sekaran, 2016).

\subsection{Research Procedure}

The questionnaires' pilot survey was done before they were fully administered to the respondents. This is to guarantee that the questionnaires are well founded as well as free from errors.

\subsection{Data Analysis Techniques}

In this study, various stages were used to analyze data. Firstly, for analysis of validity and reliability of the variables, factor analysis (FA) was done. Secondly, to present the fundamental attributes of the study data, the descriptive statistic had been utilized. Thirdly, in this study, the Pearson correlation was used to see the degree of correlation between the main variables. Lastly, multiple regressions were used to test the hypotheses; that is, to analyze the statistical significance of certain independent variables.

\section{Results and Discussion}

\subsection{Goodness of Measure Assessment}

According to Sekaran (2016), the goodness of measures for all constructs of the study can be assessed through validity and reliability tests. Moreover, this study used the exploratory factor analysis for the testing of validity and uni-dimensionality of variables' measures. On the other hand, the empirical measurements' reliability is gained through internal consistency (Sekaran, 2016) where the Cronbach's alpha test was used.

\subsection{Exploratory Factor Analysis}

For the testing of validity (the convergent and discriminant validity) of the construct, principle component analysis and Varimax rotation were used. In this research, exploratory factor analysis had been utilized to validate and ensure the goodness of measures. Table 1 displays the variables, Eigen values, percentage of variance explained, total variance explained (\%) and Kaiser-Meyer-Olkin (KMO) explained by factors. Every assumption had been satisfactorily met. Every remaining item had exceeded the suggested threshold value of 0.45 in MSA where the KMO is 0.858 (exceeded the threshold of 0.60). Meanwhile, Bartlett's sphericity test is significant ( $p>.01$ ). Therefore, factor analysis can be conducted for the items. The factor loading for all items ranged between 0.536 and 0.813 .

\subsubsection{Reliability}

For the testing of construct reliability, Cronbach's alpha was applied. Kaluyu et al. (2014) explained that reliability approximations are employed to examine two criteria. The measures' stability is examined across time over similar persons or through the utilization of similar standard (test-retest reliability), as well as the equivalent items from 
similar tests (internal consistency), or through other observations. Hair et al., (2010) stated that the Cronbach's alpha's lower limit is 0.70 . Table 1 reveals that the Cronbach's alpha for each dimension is above 0.70; which means that reliability exceeds the minimum value of $(0.70)$. As such, we can conclude that the reliability of the measures is within an acceptable range.

Table 1 . Constructs' validity and reliability results

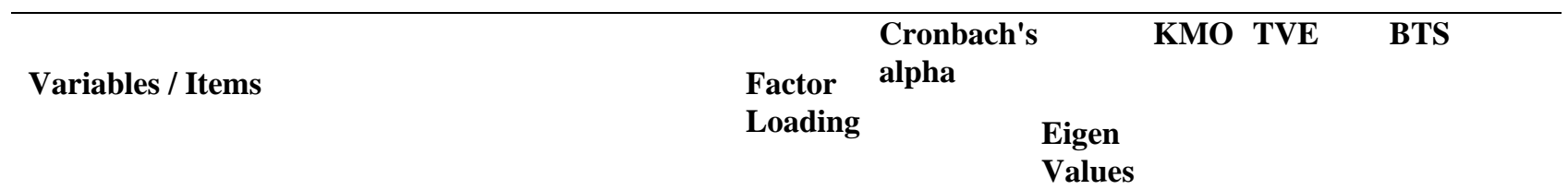

\section{Independent variable}

\section{Physical resources}

PHR1: Our university has a comprehensive library $\quad \mathbf{. 7 9 5}$ that is well prepared with different resources.

PHR2: Our university provides laboratories that.721 support educational process

PHR2: Our university has new multimedia software $\quad \mathbf{. 7 0 1}$ that is used for educational purposes and administrative operations.

PHR3: Our university provides new equipment (i.e. 696 computers, photocopiers, printers...etc.) to facilitate educational process, work procedure and administrative operations

PHR5: Our university offers extracurricular activities .622

PHR6: Our university has a special centers and .612 outdoor activities.

\section{Human Resources}

HR1: In our university, human resource management is efficient enough to ensure coherence of the organizational aim with maximum personal development of the employees

HR2: The practice and policies of human resource management accepted by all employees

HR3: Our university selects outstanding staff

HR4: Our university selects outstanding staff

.566

Independent Variable Academic performance .836 $\begin{array}{llll}5.692 & .844 & .65 .000 & 1295.518 * *\end{array}$ Eigen

Values

$\begin{array}{lllll}.836 & 5.692 & .844 & .65 .000 & 1295.518 * *\end{array}$


RP1: Our university has number of research projects.813

2.117 funded private grants

RP2: Our university has a number of successful .788 research granted application from external sources

RP3: Our university has a number of PhD students

RP4: Our university always contributes in solving complex problems through conducting research

\section{Publication performance(PP)}

PP2: In our university, one of the promotion conditions.620 is to publish in ISI Journals

PP3: Our university has a number of publications.585 sponsored by research unit

\section{Educational Performance(EP)}

EP 1: Our university has a number of international bachelor students

EP2: Our university annual intake is meeting the planned numbers.

EP3: Our university has a number of masters students

.673

.666

EP4: Our university has high student retention rate (1st.536 to 2 nd year)

\section{Training performance}

TP1: Our university has a well trained staff in the area $\mathbf{. 7 9 6}$ of research method

TP2: Our university has a number of staff who are $\quad \mathbf{. 6 0 0}$ active in research

.705

1.966

Source: prepared by the researcher from data obtained (2020)

\subsection{The Correlation and Descriptive Analysis}

Table 2 reveals the correlation and descriptive analyses for both constructs, SCs and ACP that are measured through mean and standard deviation. The table reveals that the private universities in Sudan emphasized more on physical resource (mean=3.981, standard deviation=0.727), and the lowest component of strategic capabilities is the human resource $($ mean $=3.449$, standard deviation=0.931). In view that a 5 -point scale $(1=$ strongly disagree, $5=$ strongly agree $)$ had been utilized, a conclusion can be made that the private universities operating in Sudan to some extent, are highly utilizing physical resource. Additionally, the human resource recorded a higher than average score.

Table 2 also illustrates the zero-order correlation for all dimensions of the constructs used by this study using bivariate correlations. These bivariate correlations permit the initial investigation on the hypothesized relationships. The associations between the two elements of SCs, which represent the independent variable and all the four dimensions of the ACP are distinctively positive and statistically significant. This shows that the two factors of SCs are significantly correlated with each other, given that the correlation between the variable and itself is equal to (1). Regarding ACP dimensions, Table 2 reveals that the four factors of ACP are significantly correlated with each other. The outcome of the data analysis revealed a positive relationship between strategic capabilities and academic performance in Sudanese private universities. 
Table 2. Correlation and Descriptive statistics

\begin{tabular}{|c|c|c|c|c|c|c|c|c|}
\hline Variables & Mean & $\begin{array}{l}\text { St. } \\
\text { deviation }\end{array}$ & 1 & 2 & 3 & 4 & 5 & 6 \\
\hline Physical resources & 3.981 & 0.727 & 1 & & & & & \\
\hline Human resources & 3.449 & 0.931 & $.472 * *$ & 1 & & & & \\
\hline $\begin{array}{l}\text { Research } \\
\text { performance }\end{array}$ & 1.094 & 3.100 & $.400 * *$ & $.340^{* *}$ & 1 & & & \\
\hline $\begin{array}{l}\text { Publication } \\
\text { performance }\end{array}$ & 0.992 & 3.763 & $.437 * *$ & $.427^{* *}$ & $.451^{* *}$ & 1 & & \\
\hline $\begin{array}{l}\text { Educational } \\
\text { performance }\end{array}$ & 0.742 & 3.898 & $.552 * *$ & $.405^{* *}$ & $.355^{* *}$ & $.331^{* *}$ & 1 & \\
\hline $\begin{array}{l}\text { Training } \\
\text { performance }\end{array}$ & 1.110 & 3.383 & $.338 * *$ & $.342 * *$ & $.541 * *$ & $.403 * *$ & $.362 * *$ & 1 \\
\hline
\end{tabular}

Source: prepared by the researcher from data (2020). ${ }^{* *}$ Correlation is significant at the 0.01 level (2-tailed)

\subsection{Hypotheses Testing}

The researcher had conducted the following tests prior to utilizing the multiple regression analysis to test the hypothesis. This is for the assurance that the data fit the assumptions of regression analysis. Hence, to verify that multicollinearity is absent, the VIF values and the tolerance values must be acceptable; i.e. they are below 10 and over 0.1, respectively (Hair et al., 2010). Furthermore, to test the assumption of autocorrelation, we used the test of Durbin-Watson. The results of Durbin-Watson test shown in Table 3 suggest that the assumption of autocorrelation is met as the value of Durbin Watson is (1.787), i.e. within the optimal range of 1.5-2.5, and close to 2.0.

Multiple regression had been used to predict the correlation between the dependent and independent variables. The result value of hypothesis testing is presented in Table 3, Table 4 and Table 5.

Model summary: Table 3 reveals that the value of $\mathrm{R}$ is $0.735, \mathrm{R}^{2}$ value is 0.541 , and adjusted $\mathrm{R}$ square is 0.531 . This suggests that the SCs explain approximately $46 \%$ of the variation in the ACP of private universities in Sudan.

Table 3. Model summary

\begin{tabular}{llllllll}
\hline $\mathrm{R}$ & Adjusted R & $\mathrm{R}^{2}$ & $\mathrm{~F}$ & $\mathrm{DW}$ & $\mathrm{DF}$ & $\begin{array}{l}\text { Sig } \\
\text { change }\end{array}$ \\
\hline .735 & .531 & .541 & 52.697 & 1.787 & 183 & .000
\end{tabular}

a. Predictors: (Constant)Human, Physical

b. Dependent Variable: ACP

Table 4. Anova

\begin{tabular}{|c|c|c|c|c|c|}
\hline Model & $\begin{array}{l}\text { Sum } \\
\text { squares }\end{array}$ & Df & Mean square & $\mathrm{F}$ & Sig \\
\hline Regression & 43370.884 & 4 & 10842721 & 52.697 & $.000^{\mathrm{b}}$ \\
\hline Residual & 36830.572 & 179 & 205.757 & & \\
\hline Total & 80201.457 & 183 & & & \\
\hline
\end{tabular}

a. Dependent Variable: ACP

b. Predictors: (Constant), Human, Physical

Therefore, other factors not studied in the current study may predict and explain the remaining $54 \%$ of the variation in the Academic Performance (ACP) of the private universities in Sudan.

Anova Results: Table 4, shows the relationship between strategic capabilities and academic performance is significant (H1 supported) (F statistic $=\mathbf{5 2 . 6 9 7} ; \mathrm{p}<0.001)$.

Findings of coefficient: Table 5 depicts the significant relationship between strategic capability and human resources 
$(\beta=0.359 ; \mathrm{t}=6.191 ; \mathrm{p}<0.05)$. Whereas physical resources have a positive and significant statistical relationship $(\beta=$ $0.332 ; \mathrm{t}=5.283 ; \mathrm{p}<0.05)$. Table 5 also shows the collinearity statistics.

The study's findings indicate that the correlation between strategic capabilities and academic performance is significant (H1 supported). This result is consistent with (Seyhan et al., 2017; Chen et al., 2008; Teece, 2007; Dosi et al., 2008). The findings also show that the relationship between academic performance and human resources is positive and significant (H2 supported). The results coincide with the studies conducted by (Ngugi, 2016; Osagie and Okafor, 2015). The finding of the study confirms the positive relationship between physical resources and academic performance (H3 supported). This is in line with (Angila, 2008; Akomolafe and Adesua, 2016; Wagithunu et al., 2019; Eric and Ezeugo, 2019). Moreover, this study's outcome corroborates with the result by Wagithunu et al. (2019) who examined the importance of physical resource management to the trainee teachers' academic performance in teacher training colleges in Kenya.

Table 5. Coefficient

\begin{tabular}{llllllll}
\hline Model & B & St error & Beta & T & Sig & Tolerance & VIF \\
\hline Constant & 36.739 & & & 5.584 & .000 & & \\
Human resources & 2.041 & .330 & .359 & 6.191 & .000 & .764 & 1.309 \\
Physical & 1.635 & .309 & .332 & 5.283 & .000 & .652 & 1.534 \\
resources & & & & & & & \\
\hline Depent
\end{tabular}

a. Dependent Variable: ACP

\section{Conclusions}

This study examines the relationships between human resources, physical resources and academic performance in Sudanese private universities, which is a developing country. The previous studies had examined the correlation of strategic capabilities and academic performance in developed countries. However, the previous studies in developing countries were conducted in schools, and very few in higher education. There is a limited confirmation to propose a study, which investigates the link between strategic capabilities and academic performance in developing nations' context. This study revealed that human resources and physical resources are crucial elements for academic performance. The findings implied that physical resources, and human resources play significant roles in academic performance of private universities in Sudan. Thus, all hypotheses are accepted. Based on the correlation analysis, the study found that the correlation between SCs and ACP is strong.

\subsection{Theoretical Implications}

The gap found in the literature is filled by this study. This is because this study contributes to the limited study in strategic capabilities where their role in academic performance in the higher education sector is examined. Additionally, the contribution of this study to the literature in the area of strategic management is the furnishing of ancillary proof to hold up the positive association between strategic capabilities and academic performance. As for the resource-based theory, this research reveals a conceptual framework that assists the investigation of the correlation between strategic capabilities and academic performance. However, in view that studies on SCs are growing, this study contributes to this field by determining the relationships of SCs with ACP.

\subsection{Managerial Implications}

This study's outcome provides various insights, especially for managers. First, to achieve higher performance and sustain completive advantage, managers should invest in their strategic capabilities, namely human resources and physical resources. Second, to achieve ACP, senior executives and top managers in private universities need to further enhance their aggregate resources and pay attention to SCs (human resources and physical resources). Third, to maintain a competitive position, top and middle managers have to highly concentrate on human resources (as the finding reflects higher beta) by providing training and development, encouraging teamwork and good working relationships among staff members, selecting outstanding staff as well as developing practices and policies of human resource management that are acceptable to all employees.

\subsection{Limitations and Directions for Future Research}

This research faces a few constraints that future studies could consider. This research uses a cross-sectional survey design with only quantitative measures. Other studies can conduct longitudinal data. Secondly, the data of this study are collected from a single industry (universities) and the survey could be expanded to make the findings more generalizable. Further studies may conduct comparative research of both private and public universities and investigate 
whether there are any differences based on university size. Moreover, this study uses two factors of strategic capabilities, namely human resources and physical resources. Other studies can use financial resources and technological resources with management performance in private universities. It is recommended that more research is done to examine the function of strategic capabilities along with other resources, such as organizational culture and organizational learning in sustainable competitive advantage.

\section{Acknowledgement}

We would like to express our sincere gratitude to the comments of the anonymous reviewers, as well as the representatives of private universities in Sudan whom had responded by filling-out the questionnaire; we appreciate their valuable time and effort to make this study valuable.

\section{References}

Abdalkrim, G. M. (2013). The impact of strategic planning activities on private sector organizations performance in Sudan: An empirical research. International Journal of Business and Management, 8(10), 134-139. https://doi.org/10.5539/ijbm.v8n10p134

Alboushra, M, A, Shahbudin, A. S. M., \& Abdalla, Y. A. (2015). Understanding Challenges of Performance Measurement in a Public University: Evidence from Sudan. Asian Social Science, 11(15). https://doi.org/10.5539/ass.v11n15p10

Ainuddin, R. A., Beamish, P. W., Hulland, J. S., \& Rouse, M. J. (2007). Resource attributes and firm performance in international joint ventures. Journal of World Business, 42, 47-60. https://doi.org/10.1016/j.jwb.2006.11.001

Akomolafe, C. O., \& Adesua, V. O. (2016). The Impact of Physical Facilities on Students' Level of Motivation and Academic Performance in Senior Secondary Schools in South West Nigeria. Journal of Education and Practice, 7(4), 38-42.

Anggraini, F., Abdul-Hamid, M. A., \& Azlina, M. K. A. (2018). Competitive Advantage as Mediating Role of Intellectual Capital and University Performance: An Empirical Study in Indonesia. International Journal of Economics and Management, 12(S2), 352-363.

Angila, G. A. (2008). Effective utilization of physical resources in relation to academic performance. a case study on Kimathi Primary School. Retrieved from https://su-plus.strathmore.edu/handle/11071/5138 (2nd August 2020)

Armstrong, C. E., \& Shimizu, K. (2007). A review of approaches to empirical research on the resource-based view of the firm. Journal of Management, 33(6), 959-986. https://doi.org/10.1177/0149206307307645

Aydın, O. T. (2013). Location as a Competitive Advantage to Attract Students: An Empirical Study from a Turkish Foundation University. International Review of Management and Marketing, 3(4), 204-211. https://doi.org/10.1177/0149206307307645

Barney, J. (1991). Firm resources and sustained competitive advantage. Journal of Management, 17(1), 99-120. https://doi.org/10.1177/014920639101700108

Barney, J., Wright, M., \& Ketchen, J. D. J. (2001). The resource-based view of the firm: Ten years after 1991. Journal of Management, 27(6), 625-641. https://doi.org/10.1177/014920630102700601

Bess, J. R. (2001). The building of strategic capabilities for sustainable competitive advantage: case studies in the New Zealand seafood industry: a thesis presented in partial fulfillment of the requirements for the degree of Doctor of Philosophy in Strategic Management at Massey University, Albany, New Zealand.

Carmeli, A. (2004). Assessing core intangible resources. European Management Journal, 22(1), 110-122. https://doi.org/10.1016/j.emj.2003.11.010

Chen, L. J., Chen, C. C., \& Lee, W. R. (2008). Strategic capabilities, innovation intensity, and performance of service firms. Journal of Service Science and Management, 1(02), 111. https://doi.org/10.4236/jssm.2008.12011

Crook, T. R., Ketchen Jr, D. J., Combs, J. G., \& Todd, S. Y. (2008). Strategic resources and performance: a meta-analysis. Strategic Management Journal, 29(11), 1141-1154. https://doi.org/10.1002/smj.703

Day, G. S. (1994) The capabilities of market-driven organizations. the Journal of Marketing, 37-52. https://doi.org/10.1080/09585199500000041

De Boer, H. F., Enders, J., \& Leisyte, L. (2007). Public sector reform in Dutch higher education: The organizational transformation of the university. Public Administration, 85(1), 27-46. https://doi.org/10.1111/j.1467-9299.2007.00632.x

Drucker, P. (2009). The Age of Discontinuity, Heinemann, London, (also Harper and Row). 
Dyer, I., \& Reeves, T. (1995). What do and where do we need to go? International Journal of Human Resource Management, 6(3), 656-671. https://doi.org/10.1080/09585199500000041

Eric, A., \& Ezeugo, C. R. (2019). Physical Resources Availability and the Academic Performance of Students in the Universal Basic Education Scheme, Rivers State.

Flamholtz, E., \& Lacey, J. (1981). Personnel Management: Human Capital Theory and Human Resource Accounting. Los Angeles, CA: Institute of Industrial Relations, UCLA.

Galbreath, J. T. (2004) Determinants of firm success: a resource-based analysis (Doctoral dissertation, Curtin University).

Gasim, G. (2010). Reflecting on Sudan's higher education revolution under Al-Bashir's regime. Comparative \& International Higher Education, 2(2), 50-53.

Grant, R. M. (2002). Contemporary strategy analysis; concept, technique, applications (4th ED). Mssachusetts: Blackwell.

Greene, P. G., Brush, C. G., \& Brown, T. E. (2015). Resources in small firms: an exploratory study. Journal of Small Business Strategy, 8(2), 25-40.

Hair, J. F., Anderson, R. E., Babin B. J., \& Black W. C (2010). Multivariate data analysis: A global perspective. Upper Saddle River, New Jersey, USA.

Inmyxai, S., \& Takahashi, Y. (2010). The effect of firm resources on business performance of male-and female-headed firms in the case of Lao micro-, small-and medium-sized enterprises (MSMEs). International Journal of Business and Information, 5(1). https://doi.org/10.5539/ijbm.v5n4p37

Ismail, A. I., Rose, R. C., Uli, J., \& Abdullah, H. (2012). The relationship between Organizational resources, Capabilities, Systems and Competitive Advantage. Asian academy of management Journal, 17(1).

Jeketule Soko, J. (2014). Intangible assets for sustainable competitive advantage in institutes of higher learning: A case of Kenya.

Johnson, G., \& Scholes, K. (2007). Exploring Corporate Strategy”, Sixth Edition, Prentice Hall of India.

Johnson, G., Whittington, R., Scholes, K., Angwin, D., \& Regnèr, P. (2014). Exploring Strategy Text \& Cases. Harlow, England.

Kabue, L. W., \& Kilika, J. M. (2016). Firm resources, core competencies and sustainable competitive advantage: An integrative theoretical framework. Journal of management and strategy, 7(1), 98-108. https://doi.org/10.5430/jms.v7n1p98

Kaluyu, V., Wambugu, H. W., \& Gichunge, E. (2014). Significance of Quality Assurance Mechanisms in University Strategic Management: An Advisory Model for University Managers in Kenya. European Journal of Business and Management, 6(24).

Kaplan, R. S., \& Norton, D. P. (2005). The balanced scorecard: measures that drive performance. Harvard Business Review, 83(7), 71-79.

Kiiru, G. W. (2015). Dynamic capabilities, strategic orientation and competitive advantage of small and medium-retail enterprises in Kenya (Doctoral dissertation, Jomo Kenyatta University of Agriculture and Technology).

Mahdi, O. R., \& Almsafir, M. K. (2014). The role of strategic leadership in building sustainable competitive advantage in the academic environment. Procedia-Social and Behavioral Sciences, 129, 289-296. https://doi.org/10.1016/j.sbspro.2014.03.679

Morgan, N. A., Kaleka, A., \& Katsikeas, C. S. (2004). Antecedents of export venture performance: A theoretical model and empirical assessment. Journal of Marketing, 68, 90-108. https://doi.org/10.1509/jmkg.68.1.90.24028

Mackie, B. (2008) A summary of International Organization Performance Management literature Highlighting Best Practice in Organization Performance and it' management Applicability in A central Government Context. Management Research News, 29(6), 334-344.

Ndanu, R. (2014). Determinants of Competitive Advantage among Private Universities in Kenya. Journal of Economics and International Business Research, 2(2), 17-20.

Newbert, S. L. (2008). Value, rareness, competitive advantage, and performance: a conceptual-level empirical investigation of the resource-based view of the firm. Strategic Management Journal, 29(7), 745-768. https://doi.org/10.1002/smj.686 
Ngugi, R. R. (2016). Creating Sustainable Competitive Advantage in Institutions of Higher Learning: A Case of United States International University (Doctoral dissertation, United States International University-Africa).

Nguyen, T. N. Q. (2010). Knowledge management capability and competitive advantage: an empirical study of Vietnamese enterprises.

Osagie, R. O., \& Okafor, C. J. (2015). Relationship between Human Resources Management Variables and the Academic Performance of Students in Secondary Schools in Egor Local Government Area, Edo State, Nigeria. Journal of Educational and Social Research, 5(1), 323-330. https://doi.org/10.5901/jesr.2015.v5n1p323

Othman, R., Arshad, R., Aris, N. A., \& Arif, S. M. M. (2015). Organizational Resources and Sustained Competitive Advantage of Cooperative Organizations in Malaysia. Procedia-Social and Behavioral Sciences, 170, 120-127. https://doi.org/10.1016/j.sbspro.2015.01.021

Pandza, K., \& Thorpe, R. (2009) Creative search and strategic sense-making: missing dimensions in the concept of dynamic capabilities. British Journal of Management, 20, S118-S131. https://doi.org/10.1111/j.1467-8551.2008.00616.x

Seyhan, M., Ayas, S., Sonmez, U., \& Gurlu, Y. (2017). The relationship between strategic capabilities and competitive performance: The moderating role of internal cooperation. International Journal of Academic Research in Economics and Management Sciences, 6(1), 146-161. https://doi.org/10.6007/IJAREMS/v6-i1/2603

Sekaran, U. (2016). Research Methods for Business - A Skill Building Approach, 4th ed. John Wiley \& Sons Inc., New York.

Shutibhinyo, W., \& Wongkaew, W. (2018). Strategy, Choice of Performance Measures and Use of Performance Measurement Systems: Empirical Evidence from Thailand. International Journal of Economics and Management, 12(S2), 365-375.

Smith, K. A., Vasudevan, S. P., \& Tanniru, M. R. (1996). Organizational learning and resource-based theory: an integrative model. Journal of Organizational Change Management, 9(6), 41-53. https://doi.org/10.1108/09534819610150512

Stephen, M. M., \& Nzuve, E. A. O. (2012). Study of Practice of the learning organization and its relationship to performance among Kenyan commercial Bank. Problems of Management in 21th century, 4, 45-66.

Talaja, A. (2012). Testing VRIN framework: resource value and rareness as sources of competitive advantage and above average performance. Management. Journal of Contemporary Management Issues, 17(2), 51-64.

Teece, D. J. (2007). Economic analysis and strategic management. California Management Review, 26(3), 87-110. https://doi.org/10.2307/41165082

Thompson J. L. (2007). Strategic Management: Awareness and Change, Thompson Business Publishers, 3rd Edition.

Thompson, J. L., \& Martin, F. (2010). Strategic management: awareness \& change. Cengage Learning EMEA.

Wagithunu, M. N., Edabu, P., \& Sinan, G. H. (2019). Influence of Physical Resource Management on Academic Performance of Trainees in Public Primary Teacher Training Colleges in Kenya. African Journal of Education and Practice, 4(3), 14-21.

Wang, X. (2010). Performance measurement in universities: Managerial Perspective (Master's thesis, University of Twente).

Wright, P. M., McMahan, G. C., \& McWilliams, A. (1994). Human resources and sustained competitive advantage: a resource-based perspective. International journal of human resource management, 5(2), 301-326. https://doi.org/10.1080/09585199400000020

Zikmund, W. (2003). Business research methods, 7th ed., Thomson/South-Wester.

\section{Copyrights}

Copyright for this article is retained by the author(s), with first publication rights granted to the journal.

This is an open-access article distributed under the terms and conditions of the Creative Commons Attribution license (http://creativecommons.org/licenses/by/4.0/). 